\title{
Clinical Comparison of Artemether and Quinine Treatment of Severe and Complicated Falciparum Malaria Patients in Indonesia A Preliminary Report*
}

\author{
E. Tjitra ${ }^{1}$, S. Oemijati ${ }^{2}$, S. Sulaksono ${ }^{1}$, W. Pribadi ${ }^{2}$, P.R. Arbani ${ }^{3}$, T.S. Oey ${ }^{4}$, P.N. Harianto ${ }^{5}$, S. Soemohardjo ${ }^{6}$, \\ H.A. Marwoto ${ }^{1}$, N. Syahrudji ${ }^{1}$, Sudiarso ${ }^{1}$, and S. Gunawan ${ }^{1}$
}

\begin{abstract}
Abstrak
Dalam rangka mempersiapkan obat antimalaria alternatif untuk pengobatan malaria berat dan malaria falsiparum dengan komplikasi, telah dilakukan penelitian multisenter uji perbandingan acak antara pengobatan artemeter dan kina di RS Bethesda, RSU Balikpapan dan RSU Mataram, Indonesia sejak tahun 1994. Tujuan penelitian ini adalah untuk mengetahui manifestasi klinis, menilai dan membandingkan efikasi dan keamanan artemeter intramuskular dan kina dihidroklorida intravena pada penderita dewasa malaria berat dan malaria falsiparum dengan komplikasi. Lima puluh dua orang dari 180 penderita malaria berat dan malaria falsiparum dengan komplikasi yang direncanakan, dipilih secara acak untuk diobati dengan artemeter intramuskular 1,6 mg/kg BB/dosis setiap 12 jam pada hari $O$ dan dilanjutkan dengan dosis tunggal pada hari 1-4, atau diobati dengan kina dihidroklorida intravena $20 \mathrm{mg}$ garam/kg $B B$ dalam $10 \mathrm{ml} / \mathrm{kg}$ BB Dextrosa $5 \%$ dalam 4 jam, dilanjutkan dengan $10 \mathrm{mg}$ garam $/ \mathrm{kg}$ BB/dosis setiap 8 jam dan secepatnya diganti dengan kina peroral apabila penderita dapat menelan obat. Pengobatan diteruskan sampai total mencapai 21 dosis. Mereka dirawat minimal selama 14 hari atau sampai sembuh secara klinis dan parasitologis. Dari 52 kasus malaria berat ditemukan 30 (57,7\%) kasus dengan 1 komplikasi. Komplikasi jang sering ditemukan adalah hiperbilirubinemia (50\%), malaria serebral (26,9\%) dan hiperparasitemia (25\%). Walaupun demikian angka kematian tertinggi berhubungan dengan edema paru (100\%), syok septik (100\%), perdarahan (100\%) dan hiperkreatinemia $(83,3 \%)$. Angka kemarian penderita malaria berat dan malaria falsiparum dengan komplikasi adalah 19,2\% (10/52), pada kelompok artemeter dan kina adalah 14,3\% (4/28) dan 25\% (6/24). Perbedaan tersebut secara statistik tidak bermakna. Kecenderungan kemarian meningkat dengan jumlah komplikasi dan kematian 100\% bila terdapat $>3$ komplikasi. Sampai dengan hari ke 14, tidak ada perbedaan bermakna diantara ke dua kelompok tersebut pada angka kesembuhan (100\% vs 100\%), angka rata-rata waktu bebas panas ( $34 \pm 33$ jam vs $33 \pm 17$ jam) dan bebas parasit ( $35 \pm 14$ jam vs $46 \pm 26$ jam); sedangkan angka rata-rata

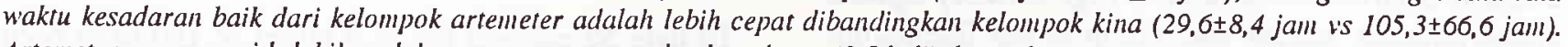
Artemeter mempunyai kelebilıan dalam mempercepat waktu kesadaran $(3,5$ kali), kecenderungan menurunkan angka kematian, sedikit dan ringan efek samping, dan lebih mudah pemberianny.
\end{abstract}

\begin{abstract}
'National Instimte of Health Research and Development, Ministry of

Health, Jakarta, Indonesia.

Indonesia, Jakarta, Indonesia.

${ }^{3}$ Directorate General of Communicable Disease Control and Emiron-

mental Health, Ministry of Health, Jakarza, Indonesia. sia.

sethesda Hospital, Tomohon, North Sulawesi, Indonesia.

${ }^{\circ}$ Mataram General Hospital, Mataram, West Nusa Tenggara, Indonesia.

This paper had been presented at British Society for Parasitology 7th Malaria Meeting. London, 19-21 September 1995.
\end{abstract}

In order to evaluate artemether as an alternative to quinine in the treatment of severe and complicated falciparum malaria, a multicenter randomized comparative study of artemether and quinine treatment was being conducted at Bethesda Hospital, Balikpapan and Mataram General Hospital, Indonesia. This study began in 1994. The objectives of this study were to determine the clinical manifestations of severe and complicated falciparum malaria, to assess and compare the efficacy and tolerance of intramuscular artemether and intravenous quinine dihydrochloride. Fifty-two out of 180 targetted severe and complicated falciparum malaria patients were randomized to receive artemerher intramuscularly $1.6 \mathrm{mg} / \mathrm{kg}$ b.w/dose bid on day 0 and followed by a daily dose on day $1-4$ or quinine dihydrochloride intravenously $20 \mathrm{mg}$ salt/kg b.w in $5 \%$ dextrose $10 \mathrm{ml} / \mathrm{kg}$ b.w in 4 hours followed by $10 \mathrm{mg}$ salt/kg b.w tid until the patient was able to swallow oral quinine up to 21 doses. They were hospitalized for at least 14 days or until clinically and parasitologically' cured. The single complication cases were found in $30(57.7 \%)$ of the 52 severe falciparum malaria patients. The most common complications were hyperbilirubinaemia (50\%), cerebral malaria (26.9\%) and hyperparasitaemia (25\%). While the highest farality rates were associated with septic shock (100\%), pulmonary edema (100\%), bleeding (100\%) and hypercreatinaemia $(83.3 \%)$. The overall case fatality rate was $19.2 \%$ (10/52). $14.3 \%(4 / 28)$ in the arsemerher group and $25 \%(0 / 24)$ in the quinine group. This difference was not statiscally significant. The risk of death increased with the number of complica tions and was 100\% if there were more than 3 complications. Until day 14, between the treatment groups, there were no significant differences in the cure rates (100\% is 100\%), mean fever clearance times $(34 \pm 33 \mathrm{~h}$ is $33 \pm 17 \mathrm{~h})$ and mean parasite clearance times ( $35 \pm 14 \mathrm{~h}$ is $46 \pm 26 \mathrm{~h}$ ). However, the mean coma 
resolution time was faster in the artemether group than in the quinine group $(29.6 \pm 8.4 \mathrm{~h}$ ws $105.3 \pm 66.6 \mathrm{~h})$. This 3.5 -fold reduction in coma duration, suggestive reduced fatality, few and mild side effects and convenience of intramuscular treatment indicated advantages of intramuscular artemether therapy.

Keywords : severe malaria, treatment, artemether, quinine.

Currently, there are chloroquine or multidrug resistant $P$. falciparum malaria cases in Indonesia. However, the proportion of resistant cases is still low except in certain parts of Indonesia ${ }^{1-2}$ (Annex 1). This phenomena is a serious public health problem. The new drugs with better efficacy need to be studied.

Severe and complicated falciparum malaria has been reported in more than $10 \%$ out of patients with falciparum malaria, with a mortality rate between 18.8 $50.0 \% .^{3-4}$ An alternative drug to reduce the complications and mortality is needed.

Artemether is an oil-based methyl ether of artemisinin and can be given by intramuscular injection. It is a rapidly acting schizontocidal drug. Clinical tiials of artemether have shown to have high efficacy against uncomplicated, severe and complicated falciparum malaria, vivax malaria, chloroquine and multidrug resistant $P$. falciparum respectively. No resistance to artemether has yet been demonstrated. ${ }^{5-7}$ Because of its ease of administration and low toxicity, artemether has replaced quinine for the first-line treatment of severe and complicated falciparum malaria in some countries. However, this drug is not yet available commercially in Indonesia. Therefore, a clinical study of artemether and quinine treatment was being performed in Indonesia to reveal the clinical manifestations of severe and complicated falciparum malaria, to assess and compare the efficacy and safety of intramuscular artemether and intravenous quinine dihydrochloride in the treatment of severe and complicated falciparum malaria in adults.

\section{METHODS}

This clinical study was a collaborative study between the Ministry of Health, Jakarta, the University of Indonesia, Jakarta, and several referral hospitals in endemic malaria areas in Tomohon, Balikpapan and Mataram, Indonesia.

\section{Study site and time of study}

The study was being carried out at the following referral hospitals: the Bethesda Hospital, Tomohon, North Sulawesi, the Balikpapan General Hospital, Balikpapan, East Kalimantan, and the Mataram General Hospital, Mataram, West Nusa Tenggara, Indonesia. The study began in 1994 .

\section{Study design}

The study was an open, randomized and comparative study of intramuscular artemether versus intravenous quinine dihydrochloride in severe and complicated falciparum malaria patients.

\section{Patients}

To date 52 patients out of a target of 180 have been recruited. The patients fulfill the WHO criteria for in vivo antimalarial sensitivity testing ${ }^{8}$. These were:

1. Over 12 years of age.

2. Non-pregnant or non-lactating females.

3. Presence of asexual forms of $P$. falciparum in blood smears.

4. No ingestion of antimalarial drug in the previous 12 hours.

5. No history of hypersensitivity to antimalarials.

6. The absence of any other serious illness.

7. Informed consent was obtained from the patients or their relatives.

The presence of one or more of the following manifestations was sufficient for the diagnosis of severe and complicated falciparum malaria ${ }^{9-12}$ :

1.Cerebral malaria

Glasgow Coma Scale (GCS) was used to assess the depth of coma. A total score of GCS less than 10 and persisting for more than 30 minutes after convulsion was considered unrousable coma.

\section{Impaired consciousness}

The unconscious malaria patient was still rousable, responded to stimulus and could be awakened. 
resolution time was faster in the artemether group than in the quinine group $(29.6 \pm 8.4 \mathrm{~h}$ vs $105.3 \pm 66.6 \mathrm{~h})$. This 3.5 -fold reduction in coma duration, suggestive reduced fatality, few and mild side effects and convenience of intramuscular treatment indicated advantages of intramuscular artemether therapy.

Keywords : severe malaria, treatment, artemether, quinine.

Currently, there are chloroquine or multidrug resistant $P$. falciparum malaria cases in Indonesia. However, the proportion of resistant cases is still low except in certain parts of Indonesia ${ }^{1-2}$ (Annex 1). This phenomena is a serious public health problem. The new drugs with better efficacy need to be studied.

Severe and complicated falciparum malaria has been reported in more than $10 \%$ out of patients with falciparum malaria, with a mortality rate between 18.8 $50.0 \% .^{3-4}$ An alternative drug to reduce the complications and mortality is needed.

Artemether is an oil-based methyl ether of artemisinin and can be given by intramuscular injection. It is a rapidly acting schizontocidal drug. Clinical trials of artemether have shown to have high efficacy against uncomplicated, severe and complicated falciparum malaria, vivax malaria, chloroquine and multidrug resistant $P$. falciparum respectively. No resistance to artemether has yet been demonstrated. ${ }^{5-7}$ Because of its ease of administration and low toxicity, artemether has replaced quinine for the first-line treatment of severe and complicated falciparum malaria in some countries. However, this drug is not yet available commercially in Indonesia. Therefore, a clinical study of artemether and quinine treatment was being performed in Indonesia to reveal the clinical manifestations of severe and complicated falciparum malaria, to assess and compare the efficacy and safety of intramuscular artemether and intravenous quinine dihydrochloride in the treatment of severe and complicated falciparum malaria in adults.

\section{METHODS}

This clinical study was a collaborative study between the Ministry of Health, Jakarta, the University of Indonesia, Jakarta, and several referral hospitals in endemic malaria areas in Tomohon, Balikpapan and Mataram, Indonesia.

\section{Study site and time of study}

The study was being carried out at the following referral hospitals: the Bethesda Hospital, Tomohon, North Sulawesi, the Balikpapan General Hospital, Balikpapan, East Kalimantan, and the Mataram General Hospital, Mataram, West Nusa Tenggara, Indonesia. The study began in 1994.

\section{Study design}

The study was an open, randomized and comparative study of intramuscular artemether versus intravenous quinine dihydrochloride in severe and complicated falciparum malaria patients.

\section{Patients}

To date 52 patients out of a target of 180 have been recruited. The patients fulfill the WHO criteria for in vivo antimalarial sensitivity testing ${ }^{8}$. These were:

1. Over 12 years of age.

2. Non-pregnant or non-lactating females.

3. Presence of asexual forms of $P$. falciparum in blood smears.

4. No ingestion of antimalarial drug in the previous 12 hours.

5. No history of hypersensitivity to antimalarials.

6. The absence of any other serious illness.

7. Informed consent was obtained from the patients or their relatives.

The presence of one or more of the following manifestations was sufficient for the diagnosis of severe and complicated falciparum malaria ${ }^{9-12}$ :

1. Cerebral malaria

Glasgow Coma Scale (GCS) was used to assess the depth of coma. A total score of GCS less than 10 and persisting for more than 30 minutes after convulsion was considered unrousable coma.

\section{Impaired consciousness}

The unconscious malaria patient was still rousable, responded to stimulus and could be awakened. 
3. Repeated generalized convulsions Malaria with more than two generalized convulsions within 24 hours although cooling had been done.

4. Prostration, extreme weakness

The malaria patient could not sit or walk with unexplainable neuropathology.

5. Fluid, electrolyte and acid-base disturbances Malaria with dehydration and or acidosis with arterial blood $\mathrm{pH}<7.25$ and plasma bicarbonate $<$ $15 \mathrm{mmol} / \mathrm{l}$.

6. Circulatory collapse (algid malaria)

Malaria with hypotension (systolic BP less than 70 $\mathrm{mm} \mathrm{Hg}$ in supine position) and signs of peripheral circulatory failure such as cold, clammy, cyanotic skin and constriction of peripheral vessels.

7. Spontaneous bleeding and clotting disorders or Disseminated Intravascular Coagulation (DIC). Malaria with retinal or subconjunctival haemorrhages, bleeding from the gums, epistaxis, melaena, haematemesis and / or signs of DIC such as increased plasma fibrinogen and decreased antithrombin III.

\section{Pulmonary edema}

Malaria with cough, a feeling of oppression in the chest and difficulty in breathing, dyspnoea, crepitations, cyanosis, convulsions and deterioration of consciousness.

9. Gastro-intestinal symptoms

Malaria with consistent vomiting and /or diarrhoea.

10. Hyperpyrexia

Malaria with body temperature (axillary) above $40.5^{\circ} \mathrm{C}$ or $105^{\circ} \mathrm{F}$.

11. Severe anaemia

Malaria with a normocytic anaemia and haematocrit less than $15 \%$ or haemoglobin less than $5 \mathrm{~g} \%$.

12. Jaundice

Malaria with jaundice, palpable liver and bilirubin more than $50 \mu \mathrm{mol} / \mathrm{l}$ or more than $3 \mathrm{mg} \%$.

13. Hypoglycaemia

Malaria with blood sugar less than $40 \mathrm{mg} \%$ or less than $2.2 \mathrm{mmol} / \mathrm{l}$, symptoms of anxiety, confusion, breathlessness, sweating and neurological symptoms.

14. Renal failure

Malaria with urine output less than $400 \mathrm{ml}$ in 24 hours after rehydration and a serum creatinine more than $265 \mu \mathrm{mol} / \mathrm{l}$ or more than $3 \mathrm{mg} \%$.

15. Haemoglobinuria and blackwater fever Malaria with black urine rather than red or brown as in other cases of massive haemolysis and Combor test positive.

\section{Hyperparasitaemia}

Malaria with the density of asexual forms of $P$. falciparum in the peripheral blood smears exceeding $5 \%$ of the erythrocytes (more than 250,000 parasite per $\mu \mathrm{l}$ at normal red cell counts).

\section{Setting}

All patients were hospitalized and observed for at least 14 days or until the patient was cured.

\section{Investigation}

A thorough history was taken and physical examinations performed on study subjects from time of admission onwards. During hospitalization, daily axillary temperatures were taken 4 hourly at $2^{\circ 0}, 6^{00}, 10^{\circ 0}$, $14^{\circ \mathrm{O}}, 18^{\circ \mathrm{O}}$ and $22^{\circ \mathrm{O}}$ until the patient became afebrile at $<37.5^{\circ} \mathrm{C}$ for 24 hours. Thereafter temperatures were taken daily.

Thick and thin blood smears were taken 12 hourly at $8^{\circ 0}$ and $20^{\circ \circ}$ for parasite counts until the asexual forms were cleared for 3 consecutive examinations. Thereafter, smears were done daily until discharged.

Routine haematology (haematocrit, haemoglobin, red cell count, white cell count, platelet count and reticulocyte count) and biochemistry (SGOT, SGPT, alkaline phosphatase, bilirubin, protein, BUN, creatinine and glucose) were done on admission (pretreatment), on discharge (post-treatment) and at other times depending on the clinical state of the patient.

Other investigations were done if clinically indicated e.g. lumbar puncture, ECG, chest X-ray and electrolyte analysis.

Patients were reviewed at least once a day.

\section{Treatment}

Twenty-eight patients were treated with intramuscular artemether at $1.6 \mathrm{mg} / \mathrm{kg} \mathrm{b} . \mathrm{w}, 12$ hourly on day 0 and daily on day 1-4. Another 24 patients were treated with intravenous quinine dihydrochloride $20 \mathrm{mg}$ salt $/ \mathrm{kg} \mathrm{b} . \mathrm{w}$ or $16.7 \mathrm{mg}$ base $/ \mathrm{kg} \mathrm{b.w}$ in $10 \mathrm{ml} / \mathrm{kg} \mathrm{b.w}$ of $5 \%$ dextrose infused in 4 hours followed by $10 \mathrm{mg}$ salt or $8.3 \mathrm{mg}$ base/kg b.w, 8 hourly. As soon as the patient could swallow the medication, intravenous quinine was replaced by oral quinine sulphate $10 \mathrm{mg}$ salt $/ \mathrm{kg}$ b.w, 8 hourly, up to a total of 21 doses. 
In addition all patients were also treated with primaquine $30 \mathrm{mg}$, single dose when the patients could swallow the drug or on the last day of treatment.

Patients who had persistent positive blood smears or negative smears followed by positive smears on day 7 or day 14 , were treated with quinine sulphate orally 10 $\mathrm{mg}$ salt/kg b.w, 8 hourly for 7 days and tetracycline $500 \mathrm{mg}, 8$ hourly for 7 days. They followed up for 14 days after treatment.

\section{Statistical analysis}

Chi-square $\left(\mathrm{X}^{2}\right)$ and Fisher's exact tests were used to compare the characteristics, clinical events and cure rate of artemether and quinine groups. Unpaired Student's t-test was used to compare the characteristics, haematology and biochemistry values, fever and parasite clearance time and coma resolution time of those groups.

\section{RESULTS}

During the study, of the total 180 targetted severe and complicated falciparum malaria patients, 52 patients have been recruited. Among them, 36, 11 and 5 cases were from Balikpapan, Tomohon and Mataram Hospital respectively. Of the 52 severe and complicated falciparum malaria, 28 cases were in the artemether group and the other 24 cases were in the quinine group. There were 40 males and 12 females; ranging in age and weight between 13 and 70 years, and 39 and $65 \mathrm{~kg}$. Less than $50 \%$ were indigenous peoples and only a few (7.7\%) had previously experienced malaria with frequency in the last 6 month ranging between 1 and 2 times. Duration of illness, axillary temperatures and parasite counts on admission ranged between 1 and 14 days, 36 and $40.6^{\circ} \mathrm{C}$, and 313 and $384,780 / \mu 1$ respectively.

\section{Comparative characteristics between treatment groups}

Comparison of the characteristics (age, sex, race, duration of illness, previous history of malaria, malaria frequency in the last 6 month, weight, axillary temperature and parasite count) revealed no significant differences between the two groups (Table 1).

Table 1. Comparison of characteristics of severe and complicated falciparum malaria patients between the treatment groups on admission at Bethesda Hospital, Balikpapan and Mataram General Hospital, Indonesia, 1994-1995.

\begin{tabular}{|c|c|c|c|}
\hline Characteristic & $\begin{array}{l}\text { Artemether } \\
\text { group* }\end{array}$ & $\begin{array}{l}\text { Quinine } \\
\text { group** }\end{array}$ & $\begin{array}{l}\text { Student's t } \\
\text { or X-test }\end{array}$ \\
\hline Age $=(x \pm S D)$ year & $27 \pm 12$ & $33 \pm 16$ & NS \\
\hline Sex $=$ male:female & $21: 7$ & $19: 5$ & NS \\
\hline Race $=$ native: others & $12: 16$ & $9: 15$ & NS \\
\hline $\begin{array}{l}\text { Duration of illness } \\
\qquad=(x \pm S D) \text { day }\end{array}$ & $8 \pm 5$ & $7 \pm 5$ & NS \\
\hline $\begin{array}{l}\text { Malaria previously } \\
\quad=y e s: n o\end{array}$ & $2: 26$ & $2: 22$ & NS \\
\hline $\begin{array}{l}\text { Malaria frequency in } \\
\text { last } 6 \mathrm{mo}=(\mathrm{x} \pm S D) \text { time }\end{array}$ & $1 \pm 0$ & $2 \pm 1$ & NS \\
\hline Weight $=(x \pm S D) k g$ & $51 \pm 6$ & $51 \pm 3$ & NS \\
\hline $\begin{array}{l}\text { Axillary temperature } \\
\quad=(x \pm S D)^{\circ} \mathrm{C}\end{array}$ & $38.5 \pm 1.1$ & $38.4 \pm 1.3$ & NS \\
\hline $\begin{array}{l}\text { Parasite count } \\
\qquad=(x \pm S D) / \mu l\end{array}$ & $47,223 \pm 60,050$ & $78,318 \pm 105,013$ & NS \\
\hline
\end{tabular}

$$
\begin{aligned}
& \star N=28 \\
& \star N=24 \\
& N S=\text { Not Significant }
\end{aligned}
$$




\section{Comparative clinical events between treatment groups}

The most frequent ( $>50 \%$ ) clinical symptoms and signs in both groups were fever, pallor, jaundice, nausea, hepatomegaly and splenomegaly. However, there were statistically no significant differences between the two groups (Figure 1).

\section{Comparative laboratory test results between treat- ment groups}

Most results of routine haematology and biochemistry examinations were abnormal on admission (pre-treatment), except the white cell and platelet counts, serum protein and glucose, which were within normal values. There were statistically no significant differences between the two groups (Table 2).

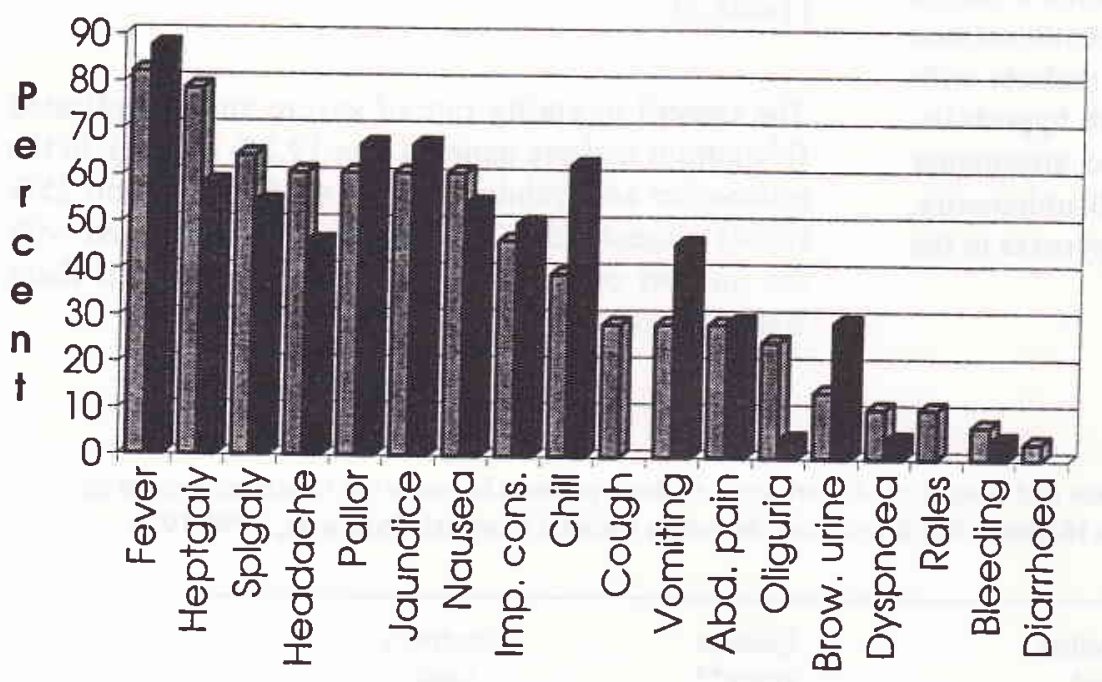

Artemeter $n=28$

Quinine $n=24$

Figure 1. Comparison of clinical events of severe and complicated falciparum malaria patients between she treatment groups on admission at Bethesda Hospital, Balikpapan and Mataram General Hospital, Indonesia 1994-1995.

Table 2. Comparison of laboratory tests of severe and complicated falciparum malaria patients between the treatment groups on admission (pre-treatment) at Bethesda Hospital, Balikpapan and Mataram General Hospital, Indonesia, 1994-1995.

\begin{tabular}{lccc}
\hline Laboratory test & $\begin{array}{c}\text { Artemether } \\
\text { group* } \\
(\mathrm{x} \pm \mathrm{SD})\end{array}$ & $\begin{array}{c}\text { Quinine } \\
\text { group* } \\
(\mathrm{x} \pm \mathrm{SD})\end{array}$ & $\begin{array}{c}\text { Student's } \\
\text { t-test }\end{array}$ \\
\hline Haematocrit (\%) & $31 \pm 8$ & $28 \pm 9$ & $\mathrm{NS}$ \\
Haemoglobin (g\%) & $9.5 \pm 3.0$ & $8.6 \pm 3.1$ & $\mathrm{NS}$ \\
Red cell count (/pl) & $3.4 \pm 1.2$ & $3.1 \pm 0.9$ & $\mathrm{NS}$ \\
White cell count (/nl) & $8.3 \pm 3.5$ & $7.5 \pm 3.7$ & $\mathrm{NS}$ \\
Platelet (nl) & $207.1 \pm 97.0$ & $177.5 \pm 45.8$ & $\mathrm{NS}$ \\
SGOT/ASAT (IU) & $52 \pm 50$ & $51 \pm 39$ & $\mathrm{NS}$ \\
SGPT/ALAT (IU) & $41 \pm 41$ & $37 \pm 26$ & $\mathrm{NS}$ \\
Alkaline phosphatase (IU) & $234 \pm 312$ & $164 \pm 73$ & $\mathrm{NS}$ \\
Total bilirubin (mg\%) & $5.9 \pm 7.6$ & $4.0 \pm 3.7$ & $\mathrm{NS}$ \\
Protein (mg\%) & $6.1 \pm 1.0$ & $6.2 \pm 0.3$ & NS \\
BUN (mg\%) & $95 \pm 114$ & $65 \pm 54$ & NS \\
Creatinine (mg\%) & $2.1 \pm 2.2$ & $1.5 \pm 1.5$ & NS \\
Glucose (mg\%) & $109 \pm 81$ & $109 \pm 29$ & \\
\hline
\end{tabular}

\footnotetext{
* $\mathrm{N}=28$

$\star * N=24$

NS $=$ Not Significant
} 
The results of all laboratory tests from both groups improved and became normal on discharge (post-treatment). There were also no significant difference between the two groups (Table 3 ).

\section{Clinical manifestations and outcomes of the treat- ment groups}

Among 52 severe and complicated falciparum malaria patients, only $30(57.7 \%)$ were cases with a single complication. The common clinical manifestations were malaria with hyperbilirubinaemia, malaria with impaired consciousness, and malaria with hyperbilirubinaemia and hyperparasitaemia in the artemether group; and also malaria with hyperbilirubinaemia, cerebral malaria, and malaria with hyperpyrexia in the quinine group (Table 4).
The most common complications of severe and complicated falciparum malaria patients were hyperbilirubinaemia (50\%), cerebral malaria (26.9\%) and hyperparasitaemia (25\%). However, the highest fatality rates were associated with pulmonary edema $(100 \%)$, bleeding $(100 \%)$, septic shock $(100 \%)$ and hypercreatinaemia $(83.3 \%)$. No fatal cases were found in patients with severe anemia and hyperpyrexia (Table 5).

The overall mortality rate of severe and complicated falciparum malaria patients was $19.2 \%$ (10/52), in the artemether and quinine group $14.3 \%(4 / 28)$ and $25 \%$ $(6 / 24)$ respectively. The risk of death increased with the number of complications and was $100 \%$ if there were more than 3 complications (Table 4).

Table 3. Comparison of laboratory tests of severe and complicated falciparum malaria patients between the treatment groups on discharge (post-treatment) at Bethesda Hospital, Balikpapan and Mataram General Hospital, Indonesia, 1994-1995.

\begin{tabular}{lccc}
\hline Laboratory test & $\begin{array}{c}\text { Artemether } \\
\text { group* } \\
(\mathrm{x} \pm \mathrm{SD})\end{array}$ & $\begin{array}{c}\text { Quinine } \\
\text { group** } \\
(\mathrm{x} \pm \mathrm{SD})\end{array}$ & $\begin{array}{c}\text { Student's } \\
\text { t-test }\end{array}$ \\
\hline Haematocrit (\%) & $35 \pm 5$ & $31 \pm 8$ & NS \\
Haemoglobin (g\%) & $10.6 \pm 2.8$ & $10.0 \pm 2.3$ & NS \\
Red cell count (/pl) & $3.6 \pm 0.9$ & $3.6 \pm 0.8$ & NS \\
White cell count (/nl) & $7.1 \pm 1.7$ & $7.0 \pm 2.8$ & NS \\
Platelet (/nl) & $336.3 \pm 158.7$ & $233.6 \pm 160.7$ & NS \\
SGOT/ASAT (IU) & $35 \pm 29$ & $40 \pm 23$ & NS \\
SGPT/ALAT (IU) & $33 \pm 23$ & $37 \pm 27$ & NS \\
Alkaline phosphatase (IU) & $147 \pm 67$ & $158 \pm 39$ & NS \\
Total bilirubin (mg\%) & $0.8 \pm 0.4$ & $0.7 \pm 0.3$ & NS \\
Protein (mg\%) & $6.8 \pm 0.9$ & $6.1 \pm 0.6$ & NS \\
BUN (mg) & $25 \pm 15$ & $26 \pm 7$ & NS \\
Creatinine (mg\%) & $0.8 \pm 0.2$ & $0.9 \pm 0.5$ & NS \\
Glucose (mg\%) & $93 \pm 38$ & $103 \pm 29$ & NS \\
\hline
\end{tabular}

\footnotetext{
$\star N=23$

$\star \star N=18$

NS $=$ Not Significant
} 
Table 4. Clinical manifestations and outcomes of the treatment groups of severe and complicated falciparum malaria patients at Bethesda Hospital, Balikpapan and Mataram General Hospital, Indonesia, 1994-1995.

\begin{tabular}{|c|c|c|c|c|c|}
\hline \multirow[t]{2}{*}{ Clinical manifestation } & Artemether & \multicolumn{2}{|c|}{ Quinine } & \multicolumn{2}{|c|}{ Total } \\
\hline & \# dead & $\#$ & dead & $\#$ & dead $(\%)$ \\
\hline
\end{tabular}

Single complication :

Hyperbilirubinaemia

Impaired consciousness

Hyperpyrexia

Severe anaemia

Cerebral malaria

Hyperparasitaemia

$\begin{array}{llllll}5 & 0 & 5 & 0 & 10 & 0 \\ 4 & 0 & 2 & 0 & 6 & 0 \\ 2 & 0 & 3 & 0 & 5 & 0 \\ 2 & 0 & 2 & 0 & 4 & 0 \\ 1 & 0 & 3 & 1 & 4 & 1 \\ 1 & 0 & 0 & 0 & 1 & 0 \\ 15 & 0 & 15 & 1 & 30 & 1(3.3)\end{array}$

Two complications :

Hyperbilirubinaemia and hyperparasitaemia Cerebral malaria and hyperbilirubinaemia

Cerebral malaria and hyperparasitaemia

Hyperbilirubinaemia and hypercreatinaemia

Cerebral malaria and severe anaemia

Hyperbilirubinaemia and severe anaemia

Hyperbilirubinaemia and pulmonary edema

$\begin{array}{ll}4 & 0 \\ 1 & 1 \\ 2 & 0 \\ 2 & 1 \\ 1 & 0 \\ 1 & 0 \\ 0 & 0\end{array}$

Subtotal

2

$\begin{array}{lllllll}11 & 2 & 4 & 2 & 15 & 4(26.7)\end{array}$

$0 \quad 0$

0

$\begin{array}{ll}4 & 0 \\ 3 & 1 \\ 3 & 1 \\ 2 & 1 \\ 1 & 0 \\ 1 & 0 \\ 1 & 1\end{array}$

2

1

0

0

0

1

0
1

1
0

0

0

\section{Three complications:}

Cerebral malaria, hyperparasitaemia and septic shock

Hyperbilirubinaemia, hypercreatinaemia and pulmonary edema

Hyperbilirubinaemia, severe anaemia and hyperparasitaemia

Hyperbilirubinaemia, hyperparasitaemia and impaired consciousness

Hyperparasitaemia, hypercreatinaemia and impaired consciousness

$\begin{array}{llllll}0 & 0 & 1 & 1 & 1 & 1 \\ 0 & 0 & 1 & 1 & 1 & 1 \\ 0 & 0 & 1 & 0 & 1 & 0 \\ 0 & 0 & 1 & 0 & 1 & 0 \\ 0 & 0 & 1 & 1 & 1 & 1 \\ 0 & 0 & 5 & 3 & 5 & 3(60.0)\end{array}$

More than three complications:

Cerebral malaria, hyperbilirubinaemia, hyperparasitaemia and hypercreatinaemia Cerebral malaria, hyperbilirubinaemia, hypercreatinaemia, pulmonary edema and bleeding

\begin{tabular}{lccccccc}
\hline Subtotal & 2 & 2 & 0 & 0 & 2 & $2(100)$ \\
Total & 28 & 4 & 24 & 6 & 52 & 10 \\
$\%$ & 100 & $14.3^{*}$ & 100 & $25^{*}$ & 100 & 19.2
\end{tabular}




\section{Comparative efficacy between treatment groups}

Of the 52 severe and complicated falciparum malaria patients, only 23 cases in the artemether group and 18 cases in the quinine group survived and had completed the study until day 14 (Table 5, 6). One case in the artemether group had not completed the study until day 14 , but survived.

By day 14 , the cure rates in both treatment group were $100 \%(23 / 23$ and 18/18). The fever clearance times ranged from 0 to 118 hours in the artemether group and from 6 to 60 hours in the quinine group. The mean fever clearance times ( $34 \pm 33$ hours vs $33 \pm 17$ hours) were not significantly different between the two treatment groups. The parasite clearance times ranged from 17 to 57 hours in the artemether group and from 12 to 137 hours in the quinine group. The mean parasite clearance times between these groups $(35 \pm 14$ hours vs
$46 \pm 26$ hours) were not significantly different. The coma resolution times of those with cerebral malaria ranged from 18 to 36 hours in the artemether group and from 48 to 195 hours in the quinine group. The mean coma resolution times between these groups were $26.6 \pm 8.4$ hours in the artemether group and $105.5 \pm 66.6$ hours in the quinine group. There was a significant difference statistically with $\mathrm{p}<0.05$ (Table 6).

\section{Comparative side effects between treatment groups}

A side effect was defined as a symptom or sign appearing only after drug administration. There were mild and self-limiting symptoms reported in both groups. In the artemether group, these were diarrhoea, itching, nausea and vomiting. While in the quinine group, these were tinitus and vertigo (Table 7).

Table 5. Complications and outcomes of the treatment groups of severe and complicated falciparum malaria patients at Bethesda Hospital, Balikpapan and Mataram General Hospital, Indonesia, 1994-1995.

\begin{tabular}{lrcrccc}
\hline Complication & \multicolumn{2}{c}{$\begin{array}{c}\text { Artemether } \\
\text { dead (\%) }\end{array}$} & \# & $\begin{array}{c}\text { Quinine } \\
\text { dead (\%) }\end{array}$ & $\begin{array}{c}\text { Total } \\
\text { dead (\%) }\end{array}$ \\
\hline Hyperbilirubinaemia & 15 & $4(26.7)$ & 11 & $2(18.2)$ & 26 & $6(23.1)$ \\
Cerebral malaria & 7 & $3(42.9)$ & 7 & $3(42.9)$ & 14 & $6(42.9)$ \\
Hyperparasitaemia & 8 & $1(12.5)$ & 5 & $3(60.0)$ & 13 & $4(30.8)$ \\
Impaired consciousness & 4 & 0 & 4 & $1(25.0)$ & 8 & $1(12.5)$ \\
Severe anaemia & 4 & 0 & 3 & 0 & 7 & 0 \\
Hypercreatinaemia & 4 & $3(75.0)$ & 2 & $2(100)$ & 6 & $5(83.3)$ \\
Hyperpyrexia & 2 & 0 & 3 & 0 & 5 & 0 \\
Pulmonary edema & 1 & $1(100)$ & 1 & $1(100)$ & 2 & $2(100)$ \\
Septic shock & 0 & 0 & 1 & $1(100)$ & 1 & $1(100)$ \\
Bleeding & 1 & $1(100)$ & 0 & 0 & 1 & $1(100)$ \\
\hline
\end{tabular}

Table 6. Comparison of antimalarial efficacy in severe and complicated falciparum malaria patients between the treatment groups until day 14 at Bethesda Hospital, Balikpapan and Mataram General Hospital, Indonesia, 1994-1995.

\begin{tabular}{|c|c|c|c|}
\hline Efficacy & $\begin{array}{l}\text { Artemether } \\
\text { group }\end{array}$ & $\begin{array}{l}\text { Quinine } \\
\text { group }\end{array}$ & $\begin{array}{l}\text { Chi-square or } \\
\text { Student's t-test }\end{array}$ \\
\hline $\begin{array}{c}\text { Cure Rate } \\
(\%)\end{array}$ & $\begin{array}{l}23 / 23 \\
100\end{array}$ & $\begin{array}{l}18 / 18 \\
100\end{array}$ & NS \\
\hline Fever Clearance Time & & & \\
\hline $\begin{array}{l}\qquad(x \pm S D) \text { hour } \\
\text { Parasite Clearance Time }\end{array}$ & $34 \pm 33$ & $33 \pm 17$ & NS \\
\hline$(x \pm S D)$ hour & $35 \pm 14$ & $46 \pm 26$ & NS \\
\hline $\begin{array}{l}\text { Coma resolution Time } \\
\qquad(x \pm S D) \text { hour }\end{array}$ & $29.6 \pm 8.4^{*}$ & $105.3 \pm 66.6^{\star *}$ & S \\
\hline
\end{tabular}

\footnotetext{
$\star N=4$

** $N=4$

NS $=$ Not Significant

$S=$ Significant $(p<0.05)$
} 
Table 7. Comparison of side effects of antimalarial in severe and complicated falciparum malaria patients between the treatment groups until day 14 at Bethesda Hospital, Balikpapan and Mataram General Hospital, Indonesia, 1994-1995.

\begin{tabular}{lcccc}
\hline Side effects & \multicolumn{2}{c}{$\begin{array}{c}\text { Artemether group* } \\
\text { \# }\end{array}$} & $\%$ & \multicolumn{2}{c}{ Quinine group** } \\
& \% & \% & $\%$ \\
\hline Diarrhoea & 1 & 4.3 & 0 & 0 \\
Itching & 1 & 4.3 & 0 & 0 \\
Nausea & 1 & 4.3 & 0 & 0 \\
Vomiting & 1 & 4.3 & 0 & 0 \\
Tinitus & 0 & 0 & 15 & 83 \\
Vertigo & 0 & 0 & 5 & 28 \\
\hline
\end{tabular}

* $\mathrm{N}=23$

$\star \star N=18$

\section{DISCUSSION}

The continuing prominence of malaria as a cause of illness and death, and the spread of resistant parasites to antimalarial drugs has become a serious problem, justifying a major effort to obtain an alternative antimalaria drug for the treatment of severe and complicated malaria.

Previous study showed that despite treatment with intravenous quinine, severe and complicated falcjparum malaria, had a fatality rate of $50 \% .{ }^{4}$ In clinical trials, artemether usually produced a more rapid therapeutic response than chloroquine, sulfadoxinepyrimethamine and quinine. ${ }^{13-16}$ Therefore, artemether is now considered as one of the antimalarial drugs of choice for severely ill patients.

This preliminary data was not sufficient to confirm the efficacy of artemether against severe falciparum measured by fever and parasite clearance times. ${ }^{13-15}$ The cure rate on day 14, mean fever and parasite clearance times between the two groups $(100 \%, 34 \pm 33$ $h$ and $35 \pm 14 \mathrm{~h}$ vs $100 \%, 33 \pm 17 \mathrm{~h}$, and $46 \pm 26 \mathrm{~h}$ ) were not significantly different. May be the sample was not large enough to show a statistically significant difference of these therapeutic responses. However, the mean coma resolution time was shorter in artemether group than in quinine group $(29.6 \pm 8.4 \mathrm{~h}$ vs $105.3 \pm 66.6$ h). Faster recovery of consciousness in cerebral malaria associated with artemether had also been reported in Malawi. ${ }^{16}$

In severe malaria, the pathological effects are due to sequestration of erythrocytes containing mature forms of parasite in the microvasculature of vital organs and causing organ damage. ${ }^{17}$ Artemether is able to prevent parasite development to the stage at which cytoadherence will limit the pathophysiological processes in severe and complicated falciparum malaria. ${ }^{18}$ However, the case fatality rate between the two groups $(14.3 \%$ vs $25 \%)$ was not significantly different. The death cases in this study were mainly with more than 2 complications and associated with fatal complications such as pulmonary edema, septic shock, bleeding and hypercreatinaemia.

In a previous study with intravenous quinine, the death cases were also mainly of patients with more than 2 complications and associated with tachypnoe, hypercreatinaemia, hyperbilirubinaemia, hypoglycaemia, leucocytosis and hypotension. The case fatality rate was higher (39\%) than the present study $(19.2 \%) .{ }^{4}$

Due to limited budget and operational reason, the patients were followed up for only 14 days. Ideally, this should be 28 days to look for recrudescence as this most occurred within 4 weeks of treatment. ${ }^{19-20}$ Hence, no recrudescence case was found up till day 14.

There were various signs and symptoms of drug intolerance in this trial. Other studies also showed that artemether had similar or no side effects, and quinine had side effects which were mild and self limiting. ${ }^{20-22}$

\section{CONCLUSION}

Artemether is a well tolerated and efficacious drug in the treatment of severe and complicated malaria. The 3.5 -fold reduction in coma duration, trend toward reduced fatality, few and mild side effects, and convenience of intramuscular treatment indicate advantages of artemether therapy over intravenous quinine therapy.

\section{ACKNOWLEDGMENTS}

The authors would like to thank the following for their invaluable assistance : the Head of Communicable Diseases Research Center, National Institute of Health Research and Development, Ministry of Health, Jakarta, Republic of Indonesia; the Head and staff of Directorate of Vector Borne Diseases, Directorate General of Communicable Diseases Control and Environmental Health, Jakarta, Indonesia; the Director and staff of Balikpapan General Hospital, Balikpapan, East Kalimantan, Indonesia; the Director and staff of Mataram General Hospital, Mataram, West Nusa Tenggara, Indonesia; the Director and staff of Bethesda Hospital, Tomohon, North Sulawesi, Indonesia; 
Kunming Pharmaceutical Factory, Kunming, China; Rhone Poulenc Rorer Doma, Jakarta, Indonesia; PT Bhineka Usada Raya, Jakarta, Indonesia; and DR Graham White, PT Zeneca, ICI Pestisida, London, UK.

\section{REFERENCES}

1. Tjitra E, Marwoto HA, Sulaksono S et al. Antimalarial drug study. Bull Hlth Studies 1992; 19 (4): 15-23.

2. Pribadi W. Drug resistance of Plasmodium falciparum in several parts of Indonesia. Symposium and worksliop on drug resistance of Plasmodium falciparum, FKUI, Jakarta, May 29-30, 1993.

3. Tjitra E. Clinical manifestations and malaria treatment. Cermin Dunia Kedokteran 1994; 94: 5-13.

4. Tjitra E and Richie TL. Preliminary report of Immunology study on cerebral malaria patients in Manado and Tomohon Hospitals, 1993- 1994. Communicable Disease Research Center, National Institute of Health Research and Development, Ministry of Health, Jakarta, 1994.

5. Bunnag D, Viravan C, Looareesuwan $S$ et al. Clinical trial of artesunate and artemether on multidrug resistance falciparum malaria in Thailand. A preliminary report. Southeast Asian J Trop Med Publ Hlth 1991; 22: 380-5.

6. Hien TT and Arnold K. Artemisinin and its derivates in the treatment of falciparum malaria in Vietnam. XIIIth International Congress for Tropical Medicine and Malaria, Jomtien, Pattaya, Thailand, 29 November - 4 December 1992.

7. Li GQ. Clinical trials on artemisinin and its derivates in treatment of malaria in China. XIIIth International Congress for Tropical Medicine and Malaria, Jomtien, Pattaya, Thailand, 29 November - 4 December 1992.

8. World Health Organization. Chemotherapy of malaria and resistance to antimalaria. Report of a WHO Scientific Group. WHO Tech Rep Ser 1973; 529.

9. WHO Malaria Action Programme. Severe and complicated malaria. Trans Roy Soc Trop Med Hyg 1990; 84 (Suppl 2): 1-65.

10. WHO Regional Office for South-East Asia. The clinical management of acute malaria. WHO Regional Publications, South-East Asia Ser no 9, 3rd ed, 1990.

11. Departemen Kesehatan. Penatalaksanaan malaria berat di Rumah Sakit dan Puskesmas. Sub Direktorat Malaria, Direktorat Jenderal Pemberantasan Penyakit Menular \&
Penyehatan Lingkungan, Departemen Kesehatan Republik Indonesia, 1990.

12. Gilles HM. Management of severe and complicated malaria. A practical handbook. World Health Organization, Geneva, 1991.

13. Myint PT and Shwee T. A controlled clinical trial of artemether (qinghaosu derivate) versus quinine in complicated and severe falciparum malaria. Trans Roy Soc Trop Med Hyg 1987; 81: 559-61.

14. Walker O, Salako LA, Risquat A. Comparative trial of im artemether (ARTM) and sulfadoxine-pyrimethamine (S-P) in severe falciparum malaria in Nigerian children. 5 th International Congress of Infectious Diseases, Nairobi, Kenya, 1992.

15. White NJ, Waller D, Crawley $J$ et al. Comparison of artemether and chloroquine for severe malaria in Gambian children. Lancet 1992; 339: 317-21.

16. Taylor TE, Wills BA, Kazembe $P$ et al. Rapid coma resolution with artemether in Malawian children with cerebral malaria. Lancet 1993; 341: 661-2.

17. White NJ and Ho M. The pathophysiology of malaria. Adv Parasitol 1992; 31: 84-175.

18. Udomsangpetch A, Kyle DE, Webster HK. Antimalarial drugs affect cytoadherence and rosetting of Plasmodium falciparum in vitro: biological and theoritical implication. The 41th Annual Meeting of The American Society of Tropical Medicine and Hygiene, Seattle, Washington, 15 - 19 November 1992.

19. Tjitra E, Oemijati S, Arbani PR and Pribadi W. Clinical trials of artesunate and artemether on falciparum malaria in chloroquine resistant areas ( A preliminary report). J Indon Med Assoc 1995; 45: 223-30.

20. Tjitra E, Pribadi W, Raharjo K et al. Treatment of uncomplicated in vitro chloroquine resistant falciparum malaria in Irian Jaya. Will be presented at 44th Annual Meeting of American Society of Tropical Medicine and Hygiene, November 17-21, 1995, San Antonio, Texas, USA.

21. Shwee T, Myint PT, Htut Y et al. The effect of mefloquineartemether compared with quinine on patients with complicated falciparum malaria. Trans Roy Soc Trop Med Hyg 1988; 82: 665-6.

22. Karbwang J, Na-Bangchang $\mathrm{K}$, Thanavibul $\mathrm{A}$ et al. Comparison of oral artemether and mefloquine in acute uncomplicated falciparum malaria. Lancet 1992; 340: 1245-8. 


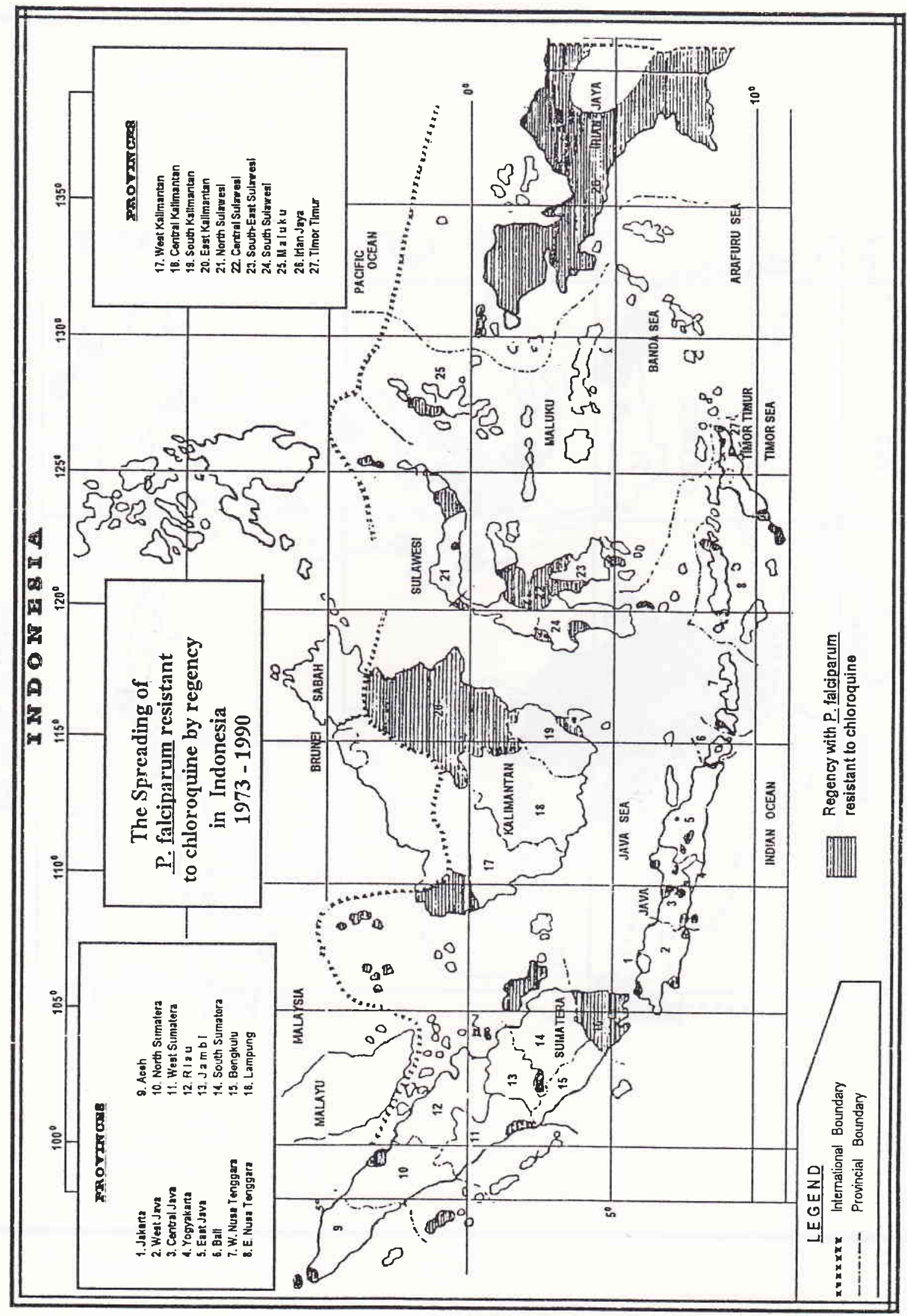




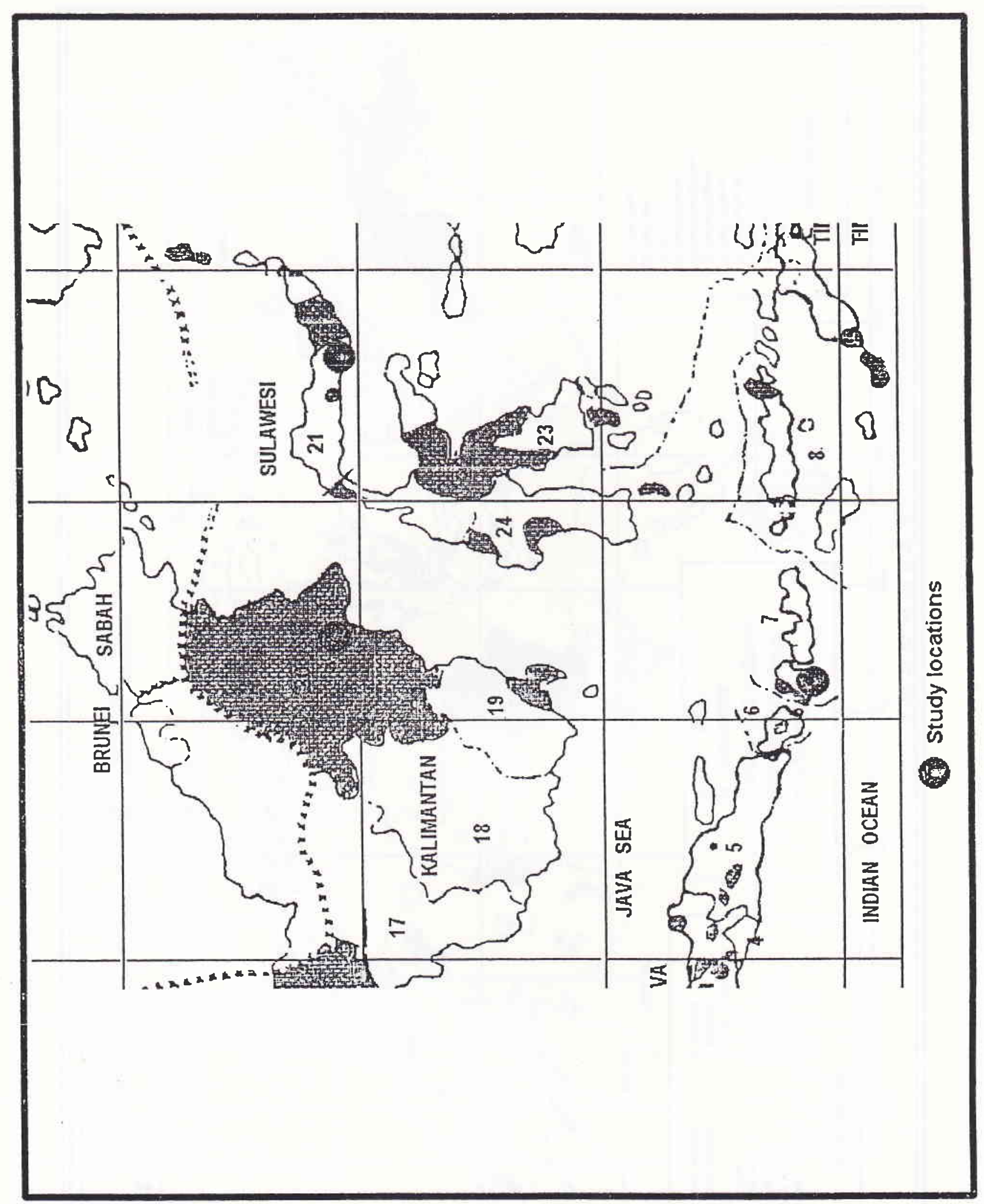

